\title{
TERRORISM ON THE SEA, PIRACY, AND MARITIME SECURITY
}

\author{
Bojan MEDNIKAROV and Kiril KOLEV
}

\begin{abstract}
Analyzing sea terrorism and its influence on maritime security, the authors reveal the main sources of this phenomenon, its character and strong connection with piracy. The article examines major tactical forms, ways and methods used by sea terrorists and the necessity to adapt the system for education of maritime personnel.
\end{abstract}

Keywords: International Terrorism, Terrorism at Sea, Maritime Security, Maritime Transport System, Piracy, Tactical Forms, Education of Maritime Personnel.

In the beginning of the $21^{\text {st }}$ century the world faces new challenges in the field of security. It appears necessary to give a new meaning to contemporary risks and the entire approach to security. It is impossible to guarantee the security only through military means. In the interest of security, it is necessary to use the wide spectrum of political, economic, military and information instruments in order to counteract the variety of risks and threats.

International terrorism is the threat most difficult to eliminate. It has worldwide importance, widens its relationship with organized crime, uses its financial resources, and unites the potential of its personnel with religious fanaticism. Technologies allow terrorists to use gaps in the protection of industrial production to access radioactive materials, as well as to create chemical and biological weapon.

Strategy of the modern terrorism includes:

- Waging psychological war trying to demonstrate the weaknesses of nations regardless of their economic and military potential;

- Declaration of religious wars to provoke conflict between civilizations and to conceal terrorist into religious aims; 
- Spreading chaos into the world economy, breaking up the trust in most developed industrial nations, increasing instability of Islamic and democratic governments;

- Creation of mass panic by using biological and chemical toxic materials, provoking feelings of helplessness;

- Threatening computer and communications systems;

- Provoking serious problems in tourism, insurance businesses, transport communications, etc.

The asymmetric character of the terrorist actions allows causing huge material and other damages using fairly limited material and human resources. In addition, among the targets of terrorist attacks are objects of a symbolic character. In some nations, destroying such objects often has considerable public impact and wide international resonance.

Main cause for terrorism is the partial or complete rejection of the existing political system. The terrorism is an external act of clearly shown or disguised political claims with economic, religious, emotional, psychological and social character. Thus, $21^{\text {st }}$ Century terrorism closely resembles some aspects of the anti-globalization movement.

Maritime terrorism is one specific expression of international terrorism. The first serious occurrence of maritime terrorist actions is the hijacking of the Italian passenger ship "Achille Lauro." This capture was carried out by a battle group of the terrorist organization "Front for Liberation of Palestine" in the Eastern Mediterranean in 1985.

The vulnerability of the military and commercial shipping to maritime terrorism was shown during the attack by the fighters of Al Qaeda against USS DDG "Cole" on October 12, 2000. This is not the only incident when the organization of Bin Laden carried out terrorist actions at sea against the USA. In 2000, of the coast of Yemen, the fighters of the organization captured a boat in order to execute attack against the USS DDG "Sullivans." They did not succeed. The boat was overloaded with explosives and nearly sunk. In 2002, again in Yemen's territorial waters, a boat used by terrorists detonated the French oil tanker SS "Limburg."

Bin Laden and businessmen, who share his ideas, own shipping companies. The companies execute illegal commercial operations used to finance the terrorists. Also in 1998, one of Al Qaeda ships delivered a great amount of explosives to Africa. Later, parts of these explosives were used in the attacks against the U.S. embassies in Kenya and Tanzania. Given sufficient amount of money, it is not difficult to turn a 
civil vessel into a semi-military one. At one point, Bin Laden spread the message that the "Al Qaeda Navy" includes 20 "naval" ships.

With the attack against the USS DDG "Cole" the terrorists aimed to provoke fear, anxiety and painful reaction in the US society. It is believed that following the example of "Al Qaeda" some Asian and Middle East terrorist groups also prepare to carry out such attacks.

On October 23, 2000, boats steered by volunteers-kamikaze from the group "Tigers for the Liberation of Tamil Eelam" destroyed a Sri Lankan naval ship and damaged another one. This terrorist organization has a subdivision called "Sea Tigers." Periodically, groups from this subdivision carry out attacks against the Sri Lankan Navy. In one of the strikes in 2001 both sides participated with total of 18 ships. In this particular strike the Sri Lankan Navy lost three patrol boats.

On 7 October 2000, a boat steered by the volunteer-suicides from "Hamas" exploded in advance, thus causing only negligible damage to an Israeli naval ship.

Bulgaria, as a sea nation, often faces problems related to maritime terrorism. The list of accidents with ships, sailing under Bulgarian flag, or vessels under foreign flag with Bulgarian crew, is very long. Terrorist and related acts are being carried out today and have happened before. They are carried out at sea, far from Bulgarian territorial waters, but also in the rivers and in our ports. Among the examples are the 1994 hijacking of the river oil tanker "Khan Kubrat," sailing under Bulgarian flag along the river Danube; the explosives found on the passenger ship "Balkan Princess" in the port of Rousse in October 2002; and the attack against the French oil tanker "Limburg" with Bulgarian crew in the territorial waters of Yemen in the same year. Incidents of pseudo-terrorism on the motor ship "Elena" and pseudo-piracy on the motor ship "Aquarius 1" deserve to be mentioned, too.

The maritime terrorism is seen as a combination of illegal actions that affect- directly or indirectly - the interests of a nation at sea or on land. These actions may be grouped into several main categories: piracy, robbery, assaults, hijacking, and illegal trafficking of weapons, people and drugs.

The origins of maritime terrorism are connected to piracy. The piracy is an old crime with international character. Roman law identifies pirates as the enemy of society Pirata hostis generis humani. The international character of pirates' attacks in the remote past is identified by:

- Protection from several nations;

- Lack of respect for sovereign rights stemming from internationally acknowledged borders and flag nation; or 
- Avoiding persecution using water areas controlled by a third nation.

There are different forms of piracy, for example maritime and coastal piracy, capers and corsairs. This crime exhibits significant stability. It not only survives, but evolves and sometimes even leaves behind public development. In the middle Ages pirates created their own quasi-state organizations with democratically elected governing bodies in accordance with precise rules. During the times of great geographic discoveries pirates were discoverers and conquerors of new lands.

In the Twentieth Century, piracy kept its place together with other acts of international organized crime. Fighting piracy is a public task. Hence, the 1958 Geneva Open Sea Convention defined ways to fight against piracy.

After the end of the Cold War terrorism and piracy continue to be a well-known phenomenon in many regions of the world. The disintegration of the bipolar political model and changes in the value systems led to the moral collapse in some social groups in the Eastern European nations. Processes of conversion and chaotic reforms in the armed forces and the intelligence services left jobless a great number of highly qualified personnel from defense and intelligence services, Special Forces and others. Moral collapse and economic crisis gave grounds for personnel with special skills to join the criminal contingent. The perfect organization and maritime training of the Somalia pirates makes viable the thesis that many among them are former coastguard officers and professional seamen.

Such circumstances facilitate 'partnerships' between partisan-terrorists and organized criminal groups. Partisan and terrorist groups have developed symbiotic links to organized crime in order to finance their activity. Thus, western democracies are confronted with the challenge to identify precisely the new enemy at sea.

Solutions of the problems of terrorism at sea and piracy are sought in the framework of the declared total war against terrorism. Many areas of the world ocean are proclaimed dangerous for shipping because of high level of pirate activity. In accordance with data of the International Maritime Bureau (IMB) in London, the number of pirate attacks on merchant vessels for the last decade tripled. ${ }^{1}$ During the period from 1998 until 2002, 1228 pirate attacks were carried out.

In the beginning of 2005, reduction of the number of pirate attacks was observed in comparison with the same period of the previous year (182 attacks for the period of January-June 2004 and 127 attacks for the period of January-June 2005). Attacks are often carried out in the area near the Somalia seacoast, the Straights of Malacca - the busiest sea area in the world with more than 50000 passing vessels per year, South China Sea, the waters near port Cochin in India. 92 vessels were attacked and 192 crew members were captured. 
Experts identify dry cargo ships and tankers as main targets of modern sea piracy. At the same time, hijacks of tugboats and hydrographic ships are also on the increase. Most vulnerable to attacks are vessels situated on the roadstead or in quay. There are many attacks against the sailing vessels.

In the IMB report on pirate attacks in the first quarter of 2003, ship owners and masters are warned to be extremely careful in planning for and passing through a number of areas, including coastal waters, straights, roadsteads and ports of ${ }^{2}$ :

- Southeastern Asia and the Indian subcontinent (Bangladesh, India, Indonesia, Malaysia, Thailand, Vietnam, Philippines, Straight of Malacca);

- Africa and the Red Sea (Conakry, Dacca, Dar es Salaam, Lagos, Aden gulf, the area near the Somalia seacoast);

- South and Central America, Caribbean (Brazil, Columbia, Dominican Republic, Ecuador, Guyana, Jamaica, Peru, Venezuela).

The first two regions are largely covered by the so-called 'strategic triangle.' The strategic triangle includes three main regions: the Persian Gulf with approximately 65 percent of the world oil reserves, the Caspian Sea and Eastern Asia. These regions provide for 49 percent of present-day output and 75 percent of oil reserves. These resources trigger conflicts between many national, regional and international interests.

The definition of exclusive economic zones in the UN Convention on the Law of the Sea leads to disputes among nations regarding their sea boarders. These are particularly severe in key regions, such as Persian Gulf, the Caspian Sea and South China Sea. There is a direct connection between the conflict of interests and limited or complete lawlessness. The lack of law and law enforcement mechanisms contributes to the increase of terrorist activity and means and methods in these regions.

The most dangerous maritime region is the area near the Somalia seacoast with a length of $3000 \mathrm{~km}$ and distance from a coastal line of $300 \mathrm{~km}$.

The regions with high concentration of pirate actions are identical to the regions of increased terrorist activity. According to the experts, the pirates in Indonesian waters and especially those acting in the Straight of Malacca are under Al Qaeda's influence. Terrorist formations also carry out pirate attacks in order to receive funding for their main activity. There is a personnel transfusion from the criminal to the terrorist direction. Pirates are often employed by terrorists to execute special political orders.

Terrorists and pirates possess faster boats, more fire power and safer communications than many of the governments in the region. Their attacks become more intensive and more effective, often causing higher number of casualties. These attacks affect negatively navies, coastguard organizations, navigation, and whole societies. Among the 
targets of terrorist attacks are vessels, port facilities, and equipment. Damages caused by maritime terrorism to the international market of cargo shipping are estimated in billions of dollars, not including fear and other psychological effects on the citizens.

Pirates cooperate actively with other criminal groups, especially those involved in illegal trafficking of drugs, weapons, and people. It is possible that pirates and other criminal organizations possess not only modern surface vessels, but also submarines. In the 1990s, Columbian drug merchants tried to build a submarine. During the same period, the US intelligence services prevented the sale of Russian submarines to Latin American criminal groups.

The analysis of modern maritime terrorism reveals a pattern - attacks at sea are carried out primarily in developing nations; about 90 percent of the attacks in the last three years. The governments of these nations are often corrupt, ineffective, incompetent and do not have the resources to counter effectively this threat. Governments do not have intelligence services, normative documents and diplomatic influence necessary to destroy terrorist and criminal organized groups. Only drastic governmental reaction against the threat of terrorist and pirate attacks could lead to the liberation of nations from the grip of the organized crime.

First prerequisite for effective reaction against the new threats is to identify correctly their specific features and origin. Maritime terrorists apply wide range of forces and means ranging from land groups trained to put improvised explosive devices on board of vessels to swimmers; fast attack boats; boats, steered by volunteer-suicides and sea mines.

According to their targets, terrorist attacks can be divided in the following categories:

- Attacks against vessels on the sea;

- Attacks against vessels in ports and at anchor, and

- Attacks against port facilities and other coastal targets.

The tactics of maritime terrorists depend on the type of the vessel, which is attacked, the value of the target, the security system of a port, the motives and operational experience of the terrorist group, etc. For example, terrorists often attack merchant vessels. Fighting swimmers are used only against immobile vessels. Fast boats are used both at high sea and near the coast (which makes them a very valuable asset; therefore, terrorist groups try hard to gain access to such boats).

Terrorists try to use the factor of surprise, which is transformed into a special element of their attacks. Terrorists prefer to carry out their attacks on vessels and port facilities in weakly protected ports. The direction of the attack is chosen depending on the weak part of the protection - it may be carried out both from the sea and from the 
coast. In well protected ports, terrorists usually concentrate their efforts only in one direction; it is possible though that terrorists choose to attack simultaneously from the sea and from the coast.

The pirate attacks, according to IMB, are of three main types. ${ }^{3}$

The first type of attacks is carried out by small maritime groups. They use fast boats to organize an ambush in waters of busiest sea routes. According to the "outer estimate" of the target, pirates determine the possibility that there is valuable cargo on board and susceptibility of the target to attack. After embarking the vessel, the attackers' goals are money in the ship's safe, valuable private possessions of the crew members or ship inventory. Expropriated possessions are transferred to pirate's fast boats. Usually, the duration of such an attack is between 30 and 40 minutes. The attackers often use violence; as a result crew members may be wounded and even killed.

During such incidents, the vessel under attack is not under the command of its crew for an extended period of time. Seamen are distracted partially or entirely from performing their professional duties and this causes potentially the gravest consequences. In some cases, the movement of supertankers during an attack is controlled only by automatic pilot, while the attack is carried out in canals, straits or other areas with busy navigation. This increases the risk of collision or stranding the ship with all resulting economic losses and grave ecological consequences.

Attacks of this kind are being carried out in the coastal waters and ports of Indonesia and the India subcontinent, West African ports, South America near Brazil, Ecuador and Columbia.

Other attacks target appropriation of the cargo and, occasionally, the vessel. Attacked crews have been killed or left to the mercy of fate in safe boats. Pirates rename a vessel and change the flag. The vessel is diverted to a port chosen in advance, where the appropriated cargo is unloaded and sold. Such attacks are well-resourced; the pirates are determined and relentless. Hijacks of vessels have often happened in coastal waters of Indonesia, the Straits of Malacca and the India subcontinent.

A third type of attacks is typical for the coastal waters of Somalia. The attacks are carried out by representatives of local paramilitary formations. Pirates kidnap members of the crew and seek ransom for their release. When a ship moves slowly or stops, e.g., due to failure of the main engine, in this area of Somalia coast, there is a high possibility that the vessel and the cargo will be hijacked or the crew - kidnapped. For example, in September 2005, pirates from Somalia captured three cargo ships of the Kenyan shipping agency "Motacu" transporting UN humanitarian aid for the population. Often pirates request ransom for ships, their crews and the cargo. One 
of the most arrogant attacks took place on November 5, 2005. At about $150 \mathrm{~km}$ off the Somalia coast two pirate fast boats reached the passenger ship "Seaborn Spirit" with approximately 300 passengers on board. The attackers launched grenades and used automatic guns. One crew member was wounded. The ship crew used a device that imitated the noise of gunfire, and successfully repelled the pirates. On the next day, a dry cargo ship, sailing in the same area, was attacked by several boats with grenades and automatic small arms. The ship was diverted by pirates who used sharp increase of speed. In the last six months of 2005 alone, 25 pirate attacks were carried out in the waters of Somalia sea coast.

The rise of terrorist and pirate attacks triggered a process of analysis and reassessment, reflected in the activity of the International Maritime Organization (IMO). ${ }^{4}$ The $83^{\text {rd }}$ Session of the Law Committee of IMO, 8-12 October 2001, set as main task for 2002-2003 the revision of the International Convention for the Suppression of Unlawful Acts against the Safety of Maritime Navigation (SULA-88). ${ }^{5}$ In February 2002, the $22^{\text {nd }}$ Assembly of IMO passed Resolution A.294 (22) and formed a Working Group on Maritime Security at the Maritime Security Committee (MSC). The group recommended changes in the international regulations for commercial navigation. Its recommendations address, iter alia, organizational and methodological aspects of the specialized training of command and other personnel in formulating and implementing ship security plans. These recommendations were transformed into resolutions at the Diplomatic Conference of Maritime Security held in London in December 2002. ${ }^{6}$ The conference passed the International Ship and Port Facility Security Code (ISPS Code) and amendments in the International Safety of Life at Sea Convention (SOLAS-74). One major change was the addition of a new chapter XI-2 in SOLAS-74 under the title "Special measures to enhance maritime security." 7

The analysis of these changes allows us to draw the following main conclusions:

- The international dimension of the problems with the security of the maritime transportation system (MTS) has increased in importance. Maritime nations enhance their cooperation in accordance with the regulations of the IMO Diplomatic Conference;

- The responsibility of each country for the security of and the support to civilian vessels sailing under its flag, as well as for the security of vessels sailing in its territorial waters increases;

- The concept of maritime security covers moving and immobile objects, subdivided according to the level of their required protection;

- The concept of maritime security is comprehensive and covers all threats to the safety of navigation. 
Changes in the regulatory framework and the results of our analysis guide the preparation of all governmental institutions, maritime and port administrations, ship owners and shipmasters of civilian vessels for implementation of the assumed duties. Of highest importance is the creation of the national legal and administrative base necessary to support the full and effective implementation of the security requirements as defined in chapter XI-2 of SOLAS-74 and the ISPS Code.

Each IMO party implements a number of activities in this regard:

- Seek a consensus among governmental agencies on international agreements on maritime security and report the stance to IMO;

- Create a national organization with responsibilities for the realization of the policy on the security of port facilities security and the communication between a port and a vessel. Seek mutual acknowledgement of national maritime security organizations while enhancing the capacity for management and control of their activities;

- Define the threats to the security of civil vessels and ports, establish the necessary security levels, and publish instructions and security guidance;

- Define precisely the term "port facilities" and nominate a security officer, responsible for planning and realization of the plans for security of port facilities;

- Define points of contact for all civil vessels that use or intend to enter the territorial waters of the country and exchange information on security levels;

- Test and ratify ship security plans and port facilities' security plans; upon ratification, amend existing plans accordingly;

- Oversee the realization of the requirements of Chapter XI-2 and part A of the ISPS Code by all vessels sailing under national flag, as well as by all national port facilities; Provide for acceptance of international security certificates awarded to ships and port facilities;

- Provide the necessary IMO information to other interested parties in accordance with the regulations;

- Inform other interested parties about the prescribed security level of the port facilities and ships that are in or intend to enter the territorial waters of the relevant nation;

- Implement measures necessary to prevent the revealing of information related to security rating of ships and port facilities and their security plans, as well as cases of penetration in the maritime security command and control system.

The IMO convention places high demands on the protection of ships, ports and security-related port facilities through a set of procedural and technical measures. It is 
recommended to use equipment with signaling and documentation functions for protection of the access to the most important-in terms of security-zones on ships, ports and port facilities.

Procedures and practices of operational control need to adhere to international and national legal norms with respect, where appropriate, to specifics of culture and religion. There are two important issues in that regard:

- Provision of respect to and protection of national economic and political interests, while guaranteeing the security of maritime communications in the region;

- Implementation of humanitarian-assistance measures in accordance with the requirements of the international legislation for protection of human life on the sea.

On its behalf, NATO has also launched a set of maritime security enhancement measures within the doctrine for Naval Cooperation and Guidance for Shipping (NCAGS). ${ }^{8}$ The doctrine describes requirements and procedures for military support, NATO guidance and control in the interests of security of the increasing trade shipping in the World Ocean, support of the military operations for protection of shipping in peacetime, in situations of tension during crisis, as well as in conflict situations. It includes different levels of consultative support and control of merchant shipping. The doctrine necessitates military coordination in a few situations of high intensity conflict.

The NCAGS organization includes the following components: theater command; operational formation; control coordinator; groups for control, including liaison officers; command of convoy service and convoy naval forces.

Planning in the regional NCAGS system is carried out by the relevant commander and headquarters. In the planning process, planners are expected to define clearly:

- Boarders of the region, where the NCAGS system deploys;

- Zones, dangerous for shipping in the region with the increased possibility of incidents;

- Points, as well as approaches, for shipping support and control (NCAGS shipping points);

- Location of the regional command and coastal and sea control groups;

- Convoy naval forces - location, optimal size and structure;

- Recommended routes and courses for shipping in the region;

- Beginning of the mobilization of the control system;

- Beginning of system deployment; 
- Duration for its activation;

- Maximum number of passing vessels per standard time period (hour, day, week, year) for all recommended routes.

NCAGS is carried out in two phases.

In the first phase, indirect control is exercised through a set of general advice and recommendations to all users. Messages containing information on possible incidents in a region, risk zones for shipping, and recommended navigation routes are transmitted to sailors. This phase begins prior to the activation of the regional system. It is realized mainly through exchange among the Navy, governmental maritime authorities and ship owners. In accordance with the decision of the regional command, complete or partial mobilization of the NCAGS system is carried out.

In the second phase of an active control, the NCAGS system is deployed. Ship masters receive obligatory directives; liaison officers accompany ships, and, potentially, the convoy service is deployed.

In critical areas (areas with possible illegal traffic of people, drugs, weapons and danger of terrorist attacks), the regional NCAGS system has several important advantages: capability for rapid and inexpensive adaptation to the existing infrastructure and the characteristics of the theater; relatively small amount of forces and means in comparison with the convoy system; maximum number of passing vessels per standard period of time and comfort for the ship owners; flexibility and adaptability to littoral waters and neighboring seas; universality for both peacetime and time of war; and high effectiveness.

The realization of the NCAGS system requires development and signing of an agreement for creation of regional structures for solving security problems in a specific region of the ocean or the sea; agreement for reciprocal exchange of security information between governmental institutions of the neighboring sea nations; agreements for organization of multinational formations and rules of engagement in pursuing and destroying civil vessels, perpetrators of terrorist actions or any other vessels carrying out illegal activities on the sea.

All recent changes in the threats, the international and national activities in preparing to meet the new threats, place new demands to the system for maritime security education. Educational institutions are not yet ready to fully satisfy these requirements. The security problems are not yet adequately presented in curricula or in specialized educational disciplines.

The training of the naval specialists and seafarers to counteract maritime terrorism and pirate activities should correspond to planned objectives and functions. No one 
expects the crews of merchant ships to solve all problems related to neutralization of terrorists. The goal is to provide training for necessary skills and adequate reaction. This reaction should create capabilities to resolve the following complex problems ${ }^{9}$ :

- To prevent a terrorist act;

- To protect life and health of crewmembers and passengers, as well as their release (if necessary);

- To support special force units neutralizing terrorists;

- To protect the ship and its cargo.

Terrorist activity on the sea has global impact. Maritime terrorism is manifested as a many-sided and complex threat against regional security. At this stage, governmental maritime authorities and Navies in some nations are not adequately prepared to execute functions of protecting shipping against maritime terrorism. In these circumstances it is necessary to improve the training of maritime specialists in countering such criminal actions.

\section{Notes:}

1 ICC International Maritime Bureau (IMB), <www.iccwbo.org/ccs/menu_imb_bureau.asp $>$ (21 Dec. 2005).

2 ICC International Maritime Bureau.

3 International Maritime Law Institute (IMLI), <www.imli.org> (21 Dec. 2005).

${ }^{4}$ International Maritime Organization (IMO), <www.imo.org/home.asp $>$ (21 Dec. 2005).

${ }^{5}$ Convention for the Suppression of Unlawful Acts against the Safety of Maritime Navigation (SULA-88).

${ }^{6}$ International Maritime Organization (IMO): Maritime security is considered an integral part of IMO's responsibilities. A comprehensive security regime for international shipping entered into force on 1 July 2004. The mandatory security measures, adopted in December 
2002, include a number of amendments to the 1974 Safety of Life at Sea Convention (SOLAS), the most far-reaching of which enshrines the new International Ship and Port Facility Security Code (ISPS Code). The ISPS code contains detailed security-related requirements for governments, port authorities and shipping companies. Some of these are mandatory (described in Part A); others, presented in Part B (non-mandatory section) provide guidelines about how to meet these requirements.

7 International Convention for the Safety of Life at Sea (SOLAS), 1974, Entry into force: 25 May 1980 (International Maritime Organization, last amendment May 2006), $<$ www.imo.org/Conventions/contents.asp?topic_id $=257 \&$ doc_id $=647>$.

8 ATP-2(B) Volume I, Naval Cooperation and Guidance for Shipping - NCAGS, NATO. For a national example see Admiral Sir Jonathon Band, "Fighting terrorism on the oceans," ENVision 3 (2002), <http://www.manw.nato.int/manw/pages/update/envision_3_02/ terrorism.htm>.

${ }^{9}$ International Maritime Law Institute.

BOJAN MEDNIKAROV is Deputy Commandant of the "N.Y. Vaptsarov" Naval Academy, Varna, with main responsibilities for education and research. He has experience as a commanding officer of fast patrol boats and operational officer in the Operational Department of the Navy Headquarters. Since 1995 he is in the educational field as lecturer, head of department in the Naval Academy and at the "Rakovsky" Defence and Staff College in Sofia. His current rank is Captain in the Navy. Dr. Mednikarov is 1984 graduate of the Naval Academy with a major in navigation and 1992 graduate of the "Kuznetsov" Naval Staff College in St. Petersburg, Russia. He received a PhD degree in systems and control in 1999. Since 2000 he is associate professor in the "N.I. Vapzarov" Naval Academy and the "G.S. Rakovsky" Defence and Staff College. Among his research interests are studies of military systems, modelling of the activities of navy units and studies of naval organizations. E-mail: bob_mednikarov@abv.bg.

KIRIL KOLEV is a Captain (ret.) in the Bulgarian Navy, born on $27^{\text {th }}$ of October 1955 in the city of Veliko Turnovo, Bulgaria. Currently he is lecturer in the Naval Academy in Varna. After graduating the Naval Academy he served at the Bourgas naval base as executive MCMS officer, operational MCMS officer, MCMS deputy commander, deputy commander of a MCMS group and the chief of staff of the MCMS division. After that he studied in the Naval Staff College in St. Petersburg. Upon graduation Capt. Kolev served as an operational staff officer and head of staff subdivision of the naval base of Varna and, later, as a lecturer in the Naval Academy, Varna. His research interests are in the theoretical and practical aspects of organization, planning and control of naval formations; organization of ship service and methods for training of tactical elements of the Navy; organization, planning and control of the MCMO of the PCO; characteristics of terrorism, anti- and counterterrorist actions; protection of shipping in emergencies. He is the author of 2 books and more than 30 articles and reports. Married with two children. 